\title{
RACHUNEK POWIERNICZY - NIEDOCENIONA FORMA ZABEZPIECZENIA OBROTU HANDLOWEGO
}

\begin{abstract}
Streszczenie. W niniejszym artykule autor przedstawia materię funkcjonującego w polskim systemie prawnym rachunku powierniczego. We wstępie opisuje definicję rachunku bankowego sensu largo i jego rodzajów w myśl prawa bankowego, a w dalszej części przechodzi do szczegółowego opisu rachunku powierniczego. Przedmiotem rozważań są zabezpieczenia dotyczące rachunku powierniczego wynikające $\mathrm{z}$ prawa bankowego, a także zastosowania tego rachunku w polskim prawie. Autor przedstawia również wnioski de lege ferenda w zakresie opisywanej materii.

Słowa kluczowe: prawo bankowe, rachunek bankowy, rachunek powierniczy, powiernik, powierzający.
\end{abstract}

\section{WPROWADZENIE}

Współczesny świat nie mógłby funkcjonować w obecnej formie, gdyby nie rachunki bankowe. Ich rola jest nieoceniona zarówno dla konsumentów, którzy przy ich pomocy dokonują transakcji bezgotówkowych oraz gromadzą na nich swoje środki pieniężne, jak i dla przedsiębiorców, którzy są zobligowani do dokonywania między sobą transakcji m.in. za pomocą rachunku bankowego, gdy wartość transakcji przekracza 15000 złotych $^{1}$.

\section{RODZAJE RACHUNKÓW BANKOWYCH W MYŚL PRAWA BANKOWEGO}

Obecnie obowiązujące przepisy prawa bankowego przewidują cztery podstawowe rodzaje rachunków bankowych ${ }^{2}$ : 1) rachunki rozliczeniowe, w tym bieżące i pomocnicze; 2) rachunki lokat terminowych; 3) rachunki oszczędnościowe, rachunki oszczędnościowo-rozliczeniowe, w tym rachunki rodzinne oraz rachunki terminowych lokat oszczędnościowych; 4) rachunki powiernicze.

*Uniwersytet Gdański, Wydział Prawa i Administracji, wojciech0guzinski@gmail.com.

${ }^{1}$ Art. 22, ust. 1 ustawy z dnia 2 lipca 2004 r. o swobodzie działalności gospodarczej (t.j. Dz. U. 2016, poz. 1829).

${ }^{2}$ Art. 49, ust. 1 ustawy z dnia 29 sierpnia 1997 r. Prawo bankowe (t.j. Dz. U. 2016, poz. 1988). 
W ujęciu charakteru prawnego umowy rachunku bankowego wskazać należy, iż umowa rachunku bankowego jest umową: nazwaną, konsensualna, dwustronnie zobowiązująca, odpłatną (Hajos-Iwańska, Lampart, Walasek 2008, 51).

Ujmując rodzaje rachunków bankowych przez pryzmat podmiotowy, należy zaznaczyć, iż (stosownie do przepisów ustawy Prawo bankowe) rachunki rozliczeniowe oraz rachunki lokat terminowych mogą być prowadzone na rzecz osób fizycznych, jednostek organizacyjnych nieposiadających osobowości prawnej, o ile posiadają zdolność prawną, a także osób fizycznych prowadzących działalność zarobkową na własny rachunek, w tym dla osób będących przedsiębiorcami, o czym stanowi art. 49, ust. 2 prawa bankowego. Natomiast stosownie do art. 49, ust. 3 prawa bankowego rachunki oszczędnościowe, rachunki oszczędnościowo-rozliczeniowe (w tym rachunki rodzinne) oraz rachunki terminowych lokat oszczędnościowych mogą być prowadzone na rzecz osób fizycznych, szkolnych kas oszczędnościowych, pracowniczych kas zapomogowo-pożyczkowych.

$\mathrm{Z}$ teleologicznego punktu widzenia rachunki bankowe wskazane powyżej w punktach 1-3 służą bieżącym rozliczeniom pomiędzy podmiotami albo stanowią lokaty o stopach zwrotu określonych w umowach o ich prowadzenie.

\section{RACHUNEK POWIERNICZY}

Odmiennie od wskazanych powyżej kształtuje się wskazany w art. 49, ust. 1, pkt 4 prawa bankowego rachunek powierniczy, który pojawił się w katalogu rachunków bankowych na mocy nowelizacji ustawy Prawo bankowe z 1 kwietnia 2004 r. (Bączyk i in. 2007, 210). Jego charakterystyka nie jest analogiczna do lokat (w większości przypadków są nieoprocentowane), nie są one też używane do standardowych rozliczeń pomiędzy stronami stosunków prawnych.

$\mathrm{Z}$ uwagi na swoją konstrukcję i funkcję rachunek powierniczy, obok m.in. depozytu notarialnego, depozytu sądowego, poddania się egzekucji w trybie art. 777 Kodeksu postępowania cywilnego, gwarancji ubezpieczeniowej lub bankowej, weksla albo poręczenia, stanowi jedną z funkcjonujących $\mathrm{w}$ polskim systemie prawnym form zabezpieczenia transakcji pomiędzy podmiotami, szczególnie w obrocie gospodarczym.

Funkcjonowanie rachunku powierniczego związane jest w znacznej mierze ze stosunkiem powiernictwa. W myśl art. 59, ust. 1 prawa bankowego na rachunku tym mogą być gromadzone środki pieniężne powierzone posiadaczowi rachunku przez osobę trzecią na podstawie osobnej umowy. Zauważyć należy, iż ustawodawca w ustawie nie wskazał, czy występuje tutaj kontrakt typu fiducjarnego, który charakteryzuje się tym, iż występuje $\mathrm{w}$ nim przeniesienie na powiernika własności środków pieniężnych, czy również powierzenie w sensie technicznoprawnym (Stec 2005, 232). 
Obok wyliczenia wynikającego z przywołanego już art. 49 prawa bankowego, rachunkowi powierniczemu poświęcono unormowanie zawarte w art. 59 prawa bankowego. Wobec braku odmiennej, szerszej regulacji stosuje się do niego przepisy ogólne prawa bankowego oraz przepisy Kodeksu cywilnego, ze szczególnym uwzględnieniem art. 725-733 tej ustawy, tj. tych dotyczących umowy o prowadzenie rachunku bankowego.

Stosownie do treści art. 59, ust. 2 prawa bankowego stronami umowy rachunku bankowego są dwa podmioty: bank prowadzący rachunek oraz powiernik, czyli posiadacz rachunku, a w myśl wspomnianego już art. 59, ust. 1 tejże ustawy na rachunku tym mogą być gromadzone wyłącznie środki pieniężne powierzone posiadaczowi rachunku - na podstawie odrębnej umowy (umowy powierniczej) - przez osobę trzecią, tj. powierzającego, który, co wymaga podkreślenia, nie jest stroną umowy o prowadzenie przedmiotowego rachunku bankowego.

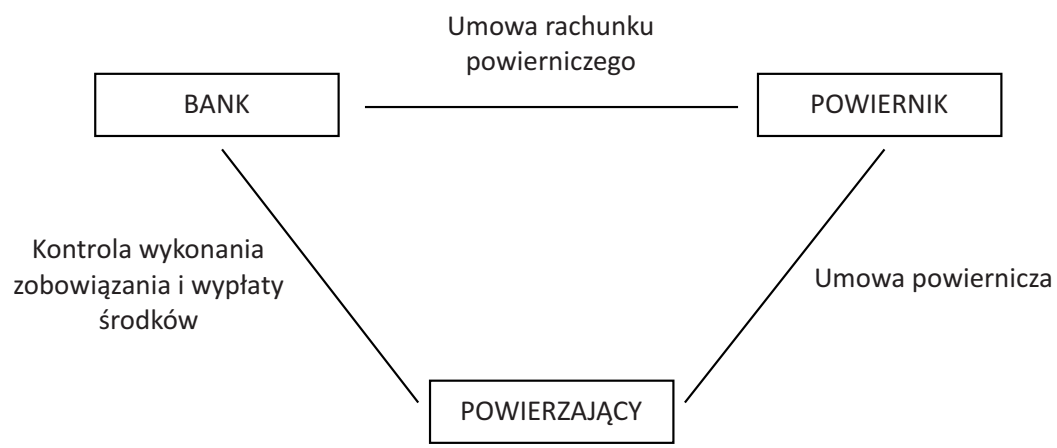

Diagram 1. Schemat zależności pomiędzy podmiotami obecnymi w procesie obsługi rachunku powierniczego

Zamieszczony diagram, oprócz wyżej wskazanych regulacji, ukazuje, iż pomiędzy bankiem a powierzającym nie występuje żaden łączący ich umowny stosunek prawny.

W praktyce rachunek powierniczy stosowany jest przez podmioty gospodarcze. Powiernik na gruncie umowy powierniczej zobowiązany jest do odpłatnego świadczenia określonych usług względem powierzającego. W celu zabezpieczenia obu stron, np. przed upadłością bądź ryzykiem postępowania egzekucyjnego, zleceniodawca $\mathrm{w}$ tym stosunku prawnym może przekazać powiernikowi wynagrodzenie „z góry” celem zabezpieczenia jego przyszłego wynagrodzenia. Kwota ta ulega quasi-blokadzie na rachunku powierniczym. Powiernik otrzyma ją po spełnieniu warunków określonych w umowie rachunku powierniczego (Kaszubski, Tupaj-Cholewa 2010, 45).

Wobec powyższego, idea funkcjonowania rachunku powierniczego polega jednak na tym, że bank pełni funkcję ochronną dla powierzającego, ponieważ 
kontroluje, czy zobowiązanie spełnione na rzecz powierzającego przez powiernika wykonywane jest zgodnie z treścią umowy rachunku powierniczego. Stosownie do brzmienia art. 59, ust. 3 prawa bankowego, umowa o prowadzenie rachunku powierniczego określa warunki, jakie powinny być spełnione, aby środki pieniężne osób trzecich (powierzających) wpłacone na rachunek mogły być wypłacone posiadaczowi rachunku lub aby jego dyspozycje w zakresie wykorzystania tych środków mogły być zrealizowane. Oznacza to, że to decyzja banku w zakresie spełnienia wymogów z umowy rachunku powierniczego jest wiążąca zarówno dla powierzającego, jak i powiernika. Warty nadmienienia jest fakt, że treść umowy powierniczej zawartej pomiędzy powierzającym i powiernikiem nie musi być nawet znana bankowi, ten zaś powinien wiedzieć o samym istnieniu stosunku powiernictwa (Bączyk i in. 2007, 211). Co więcej, wykorzystanie gromadzonych środków niezgodnie z przeznaczeniem albo przechowywanie środków własnych powiernika może być w myśl art. 730 k.c. traktowane jako „ważny powód” i stanowi przesłankę uprawniającą bank do wypowiedzenia umowy o prowadzenie tego rachunku (Kaszubski, Tupaj-Cholewa 2010, 46). Fakt, że stosownie do treści art. 59 ust. 2 prawa bankowego stronami umowy rachunku powierniczego są bank i posiadacz rachunku (powiernik), implikuje, iż powierzający nie jest stroną umowy rachunku powierniczego, co w konsekwencji powoduje, że nie ma on podstawy do kontroli rachunku powierniczego np. poprzez zażądanie udzielenia informacji o stanie środków na rachunku powierniczym albo o dokonanych z rachunku powierniczego wypłatach (Kawulski 2013).

Ustawą z dnia 10 czerwca 2016 r. zmieniającą ustawę Prawo bankowe wprowadzono obowiązek, w myśl którego wpłaty na rachunek powierniczy powinny być identyfikowalne, tj. w każdym czasie powinna być możliwa identyfikacja osób, które wpłaciły środki pieniężne na ten rachunek, a także powinno być możliwe obliczenie ich udziału w całościowej kwocie zgromadzonej na rachunku powierniczym, o czym stanowi art. 59, ust. 3a prawa bankowego. Miałoby to zapobiec sytuacji, w których wpłaty powierzających mieszałyby się ze soba, tworząc jedną nieidentyfikowaną masę, bowiem niejednokrotnie jest więcej niż jeden powierzający. W praktyce powierzający zwykle posiadają swoje subkonta do głównego rachunku powierniczego, na które wpłacają określone w umowie powierniczej kwoty pieniężne.

\section{MECHANIZMY OCHRONNE WYNIKAJĄCE Z RACHUNKU POWIERNICZEGO}

Niezależnie od powyższego, sam fakt, że bank pełni funkcję „strażnika” prawidłowości wykonania zobowiązania wynikającego z umowy powierniczej nie wyczerpuje katalogu środków ochrony podmiotów związanych rachunkiem powierniczym, bowiem nie bez znaczenia są również inne regulacje zawarte w art. 59 prawa bankowego. 
Powyżej wskazane zostało, iż bank nie musi znać treści umowy powierniczej. Jednak stosownie do treści art. 59, ust. 7 prawa bankowego, jeżeli powierzenie środków pieniężnych nastąpiło w wykonaniu umowy powierniczej z datą pewną, to wobec środków zgromadzonych na rachunku powierniczym stosuje się szereg dodatkowych zabezpieczeń, które mają na celu zabezpieczenie interesów osób trzecich (Kawulski 2013). Przepis ten warunkuje zatem dodatkowe zabezpieczenia od zawarcia umowy $\mathrm{z}$ data pewną. $\mathrm{W}$ praktyce zwykle oznacza to zawarcie umowy powierniczej $\mathrm{w}$ formie aktu notarialnego (forma ta bowiem ex lege zawiera w sobie datę pewna) bądź w formie pisemnej z podpisami notarialnie poświadczonymi stosownie do treści art. 81, 2 , pkt 2 k.c. Możliwe jest także zawarcie umowy $\mathrm{w}$ formie pisemnej z datą poświadczoną notarialnie, stosownie do treści art. 99 ustawy Prawo o notariacie, albowiem urzędowe poświadczenie daty dokonane przez notariusza na okazanym mu dokumencie, w którym stwierdza on datę okazania, oznacza datę pewną (Radwański 2009, 233).

W przypadku zawarcia umowy powierniczej z datą pewną, na okoliczność wszczęcia postępowania egzekucyjnego przeciwko powiernikowi środki zgromadzone na rachunku powierniczym są wyłączone spod egzekucji - nie podlegają zajęciu w toku postępowania egzekucyjnego; nie stosuje się wobec tego rodzaju rachunku bankowego art. 889 i następnych k.p.c. Niniejsze rozwiązanie, wskazane w art. 59, ust. 4 prawa bankowego, stanowi ochronę środków powierzającego, które złożone zostały na rachunku powierniczym celem wykonania zobowiązania określonego w umowie powierniczej. Co więcej, rozwiązanie to chroni powierzającego przed negatywnymi skutkami postępowania egzekucyjnego, które prowadzone jest przeciwko powiernikowi, a które może nie mieć jakiegokolwiek związku ze stosunkiem powierniczym (Ofiarski 2008, 131). Należy bowiem pamiętać, iż powierzający, wpłacając pieniądze na rachunek powierniczy powiernika, nie ma już do nich dostępu, co tworzy ryzykowną sytuację dla powierzającego (Kaszubski, Tupaj-Cholewa 2010, 46). Problematyczna może być jednak sytuacja, w której to powierzający jest wierzycielem, a powiernik dłużnikiem, albowiem wierzyciel, czyli powierzający, jest zmuszony prowadzić egzekucję z pozostałych składników majątkowych powiernika, czyli dłużnika, z wyłączeniem rachunku powierniczego. Zagadnienie to de lege ferenda wymaga ingerencji ustawodawcy poprzez wyłączenie stosowania wobec powierzającego (Kawulski 2013).

Kolejnym mechanizmem chroniącym interesy powierzającego i środków, które złożył na rachunku powierniczym jest wskazana w art. 59, ust. 5 prawa bankowego ochrona na okoliczność upadłości powiernika. Stosownie do treści niniejszego artykułu, w razie ogłoszenia upadłości powiernika środki pieniężne znajdujące się na tym rachunku podlegają wyłączeniu z masy upadłościowej (jeżeli umowa powiernicza zawarta była $\mathrm{z}$ datą pewną). Jest to lex specialis $\mathrm{w}$ stosunku do ogólnych przepisów przyjętych w ustawie Prawo upadłościowe, albowiem środki na rachunku powierniczym nie wchodzą w skład spisu inwentarza sporządzanego przez syndyka po ogłoszeniu upadłości. Przepis prawa bankowego 
nie wskazuje jednak, jak należy traktować wyłączone z masy upadłościowej środki zgromadzone na rachunku powierniczym. Tego typu rozwiązanie zawiera przewidująca specjalny rodzaj rachunku powierniczego ustawa z dnia 16 września 2011 r. o ochronie praw nabywcy lokalu mieszkalnego lub domu jednorodzinnego, w której przepisy prawa upadłościowego objęły deweloperów postępowaniem odrębnym. Być może ustawodawca de lege ferenda powinien unormować wyłączenie środków zgromadzonych na rachunku powierniczym z masy upadłościowej na gruncie obecnie funkcjonujących przepisów prawa upadłościowego.

Przy legislacyjnym opracowaniu zagadnienia rachunku powierniczego w prawie bankowym ustawodawca unormował także kwestię dziedziczności środków na nim się znajdujących. Ustawa Prawo bankowe z treści art. 55 wyłączyła rachunki powiernicze. W art. 59, ust. 6 ustawy Prawo bankowe wskazano, iż środki zgromadzone na rachunku powierniczym nie wchodzą w skład spadku po posiadaczu rachunku, tj. powierniku, czyli nie są dziedziczone przez spadkobierców powiernika. Dla istnienia tego zabezpieczenia niezbędne było zawarcie umowy powierniczej z datą pewną. Wskazania wymaga, że również w tym wypadku nie występują dalsze normatywne dyspozycje pozwalające rozporządzić środkami zgromadzonymi na rachunku powierniczym. Nie istnieje jednolite stanowisko $\mathrm{w}$ zakresie dotyczącym tej materii. $\mathrm{Z}$ jednej strony wskazuje się, że nie ma w polskim systemie prawnym normy kompetencyjnej, która umożliwiłaby powiernikowi dokonanie rozporządzenia tą wierzytelnością wskutek jednostronnej czynności prawnej mortis causa na korzyść powierzających. Z drugiej strony jednak podnosi się, że wierzytelność ta wchodzi do spadku powierzającego (Kawulski 2013). Norma wynikająca z art. 59, ust. 3a prawa bankowego, nakazująca prowadzenie rachunku powierniczego w sposób umożliwiający identyfikację wpłacających, ułatwia w tym przypadku wskazanie wysokości wierzytelności powierzającego.

\section{ESCROW - QUASI-RACHUNEK POWIERNICZY}

Analizując materię rachunku powierniczego, należy nadmienić, abstrahując od ustawy Prawo bankowe, iż praktyka bankowa dopuszcza również funkcjonowanie na zasadzie swobody umów z art. $353^{1}$ k.c. tzw. rachunku Escrow. Różnica pomiędzy rachunkiem powierniczym umocowanym w ustawie Prawo bankowe a rachunkiem Escrow polega na tym, że otwierany jest on nie na podstawie umowy pomiędzy powiernikiem a bankiem, jak ma to miejsce w przypadku rachunku powierniczego, lecz na podstawie trójstronnej umowy pomiędzy powiernikiem, powierzającym i bankiem. Niemniej jednak, z uwagi na fakt, iż jest to $\mathrm{w}$ ujęciu cywilistycznym umowa nienazwana, nie korzysta ona $\mathrm{z}$ omówionych już przywilejów zawartych w art. 59 ustawy Prawo bankowe (Kaszubski, Tupaj-Cholewa 2010, 47). 


\section{OBLIGATORYJNOŚĆ STOSOWANIA RACHUNKU POWIERNICZEGO W POLSKIM SYSTEMIE PRAWNYM}

W polskim systemie prawnym istnieje ustawowo nałożony obowiązek stosowania rachunku powierniczego w dwóch sferach, w których często dochodziło do nadużyć i szczególnego pokrzywdzenia konsumentów - w turystyce i branży deweloperskiej.

Ustawa z dnia 29 sierpnia 1997 r. o usługach turystycznych wskazuje, że przedsiębiorca wykonujący działalność gospodarczą w zakresie organizowania imprez turystycznych oraz pośredniczenia na zlecenie klientów w zawieraniu umów o świadczenie usług turystycznych jest obowiązany spełniać wskazane w ustawie obowiązki dotyczące jak najpełniejszego zabezpieczenia roszczeń klientów poprzez zawarcie umowy gwarancji bankowej lub ubezpieczeniowej lub zawarcie umowy ubezpieczenia na rzecz klientów, lub przyjmowanie wpłat klientów wyłącznie na rachunek powierniczy, jeżeli wykonuje usługi turystyczne wyłącznie na terenie kraju i złoży właściwemu marszałkowi województwa oświadczenie o przyjmowaniu wpłat na rachunek powierniczy, oraz dokonywanie terminowych wpłat składki w należnej wysokości do Turystycznego Funduszu Gwarancyjnego. Wobec tego podmiot organizujący albo pośredniczący w zakresie organizowania imprez turystycznych może starać się o gwarancję bankową lub ubezpieczeniowa, albo zawrzeć umowy ubezpieczenia z umocowaniem na rzecz klientów, albo pobierać wpłaty na rachunek powierniczy. Postawienie rachunku bankowego obok gwarancji bankowej i gwarancji ubezpieczeniowej świadczy o przekonaniu ustawodawcy, iż rachunek powierniczy stanowi skuteczne zabezpieczenie transakcji.

Ustawa z dnia 11 września 2011 r. o ochronie praw nabywcy lokalu mieszkalnego lub domu jednorodzinnego zawiera w swojej treści cały rozdział poświęcony gromadzeniu środków wpłacanych przez nabywców na rachunku powierniczym dewelopera. Deweloper dla każdego przedsięwzięcia deweloperskiego zawiera umowę o prowadzenie otwartego albo zamkniętego mieszkaniowego rachunku powierniczego, zwanego dalej ,mieszkaniowym rachunkiem powierniczym". W przywołanej ustawie mamy do czynienia z sytuacja, gdzie pojawia się lex specialis $\mathrm{w}$ stosunku do umowy rachunku powierniczego z ustawy Prawo bankowe. Podniesienia wymaga fakt, iż jest to sytuacja wyjątkowa, albowiem lex specialis zawiera bardziej szczegółową i dokładną regulację niż lex generalis. Ustawa wskazuje, że mieszkaniowy rachunek powierniczy może mieć formę otwartą bądź zamkniętą. Otwarty mieszkaniowy rachunek powierniczy charakteryzuje się tym, że bank wypłaca deweloperowi środki zgromadzone na otwartym mieszkaniowym rachunku powierniczym po stwierdzeniu zakończenia danego etapu realizacji przedsięwzięcia deweloperskiego. W praktyce bank wysyła osobę posiadającą odpowiednie uprawnienia budowlane w celu sprawdzenia dziennika budowy oraz przeprowadzenia wizji lokalnej na placu budowy. Etapy realizacji 
przedsięwzięcia deweloperskiego wskazane są w umowach deweloperskich klientów. W przypadku zamkniętego mieszkaniowego rachunku powierniczego bank wypłaca deweloperowi środki pieniężne wpłacone przez nabywcę na zamknięty mieszkaniowy rachunek powierniczy po otrzymaniu odpisu aktu notarialnego umowy przenoszącej na nabywcę prawo odrębnej własności lokalu mieszkalnego albo prawo własności nieruchomości zabudowanej domem jednorodzinnym lub użytkowania wieczystego nieruchomości gruntowej i własności domu jednorodzinnego na niej posadowionego stanowiącego odrębną nieruchomość, w stanie wolnym od obciążeń, praw i roszczeń osób trzecich, z wyjątkiem obciążeń, na które wyraził zgodę nabywca (np. hipotek umownych).

\section{KONKLUZJE}

Powyższe wskazuje, iż rachunek powierniczy może stanowić skuteczne zabezpieczenie interesów powierzających w transakcjach handlowych dzięki szeregowi mechanizmów zawartych w ustawie Prawo bankowe. Niemniej jednak, pomimo że przepis funkcjonuje w ustawie Prawo bankowe od wielu lat, to nadal zawiera szereg niedoskonałości, które powinny być przedmiotem działań ustawodawcy. Wydaje się również, że rachunek powierniczy jest mało rozpowszechnioną formą zabezpieczania transakcji handlowych. Można przypuszczać, iż jest to spowodowane ogólną nieznajomością tej formy zabezpieczenia, a ponadto stosunkowo skomplikowaną procedura, która wymaga podpisania co najmniej dwóch umów, a także ponoszenia kosztów związanych z obsługą tego rachunku przez bank. Przedsiębiorcy chętniej stosują np. depozyty notarialne albo zawierają umowy w formie aktów notarialnych z zawartymi klauzulami z art. 777 k.p.c., głównie z tego względu, iż procedury te są zdecydowanie szybsze i korzystniejsze ekonomicznie. Nie bez znaczenia jest też fakt, że ustawodawca nakłada obowiązek stosowania rachunku powierniczego jedynie w dwóch wypadkach, pomimo iż rachunek powierniczy mógłby stanowić zabezpieczenie interesów Skarbu Państwa, np. poprzez obowiązek rozliczania inwestycji publicznych przy pomocy rachunku powierniczego.

\section{BIBLIOGRAFIA}

Bączyk, Mirosław, Eugenia Fojcik-Mastalska, Lesław Góral, Jerzy Pisuliński, Wojciech Pyzioł. 2007. Prawo bankowe. Komentarz. Warszawa: LexisNexis.

Hajos-Iwańska, Agnieszka, Marta Lampart, Wojciech Walasek (red.). 2008. Prawo bankowe. Warszawa: Wolters Kluwer.

Kaszubski, Remigiusz, Agata Tupaj-Cholewa. 2010. Prawo bankowe. Warszawa: Wolters Kluwer. Kawulski, Arkadiusz. 2013. Prawo bankowe. Komentarz. Warszawa: LexisNexis.

Ofiarski, Zbigniew. 2008. Prawo bankowe. Warszawa: Wolters Kluwer. 
Radwański, Zbigniew. 2009. Prawo cywilne - część ogólna. Warszawa: C.H. Beck.

Stec, Piotr. 2005. Powiernictwo w prawie polskim na tle porównawczym. Kraków: Kantor Wydawniczy Zakamycze.

Wojciech Guziński

\title{
FIDUCIARY ACCOUNT - AN UNDERESTIMATED FORM OF COMMERCIAL TRADING SECURITY
}

\begin{abstract}
In this article the author presents the matter of fiduciary account functioning in the Polish legal system. In the introduction there is the definition of a bank account in the broader sense and its kinds in accordance with banking law and later the author moves on to a detailed description of the fiduciary account. The consideration concerns security due to a bank account under the banking law and the application of the fiduciary account in Polish law. The author also presents conclusions de lege ferenda in the described matter.
\end{abstract}

Keywords: banking law, bank account, trust account, confidant, conferring. 